\title{
Correction to: A Demonstration of Caregiver-Implemented Functional Analysis of Inappropriate Mealtime Behavior Via Telehealth
}

\author{
Ashley S. Andersen ${ }^{1} \cdot$ Bethany A. Hansen ${ }^{1} \cdot$ Kristin L. Hathaway ${ }^{1} \cdot$ Lindsey A. Elson $^{1}$ \\ Published online: 26 July 2021 \\ (C) This is a U.S. government work and not under copyright protection in the U.S.; foreign copyright protection may apply 2021
}

Correction to: Behavioral Analysis in Practice. https://doi.org/10.1007/s40617-021-00615-2

This article was updated to correct the second sentence of the article.

Publisher's Note Springer Nature remains neutral with regard to jurisdictional claims in published maps and institutional affiliations.

The online version of the original article can be found at https://doi.org/ 10.1007/s40617-021-00615-2

Bethany A. Hansen

bethany.hansen@unmc.edu

1 Munroe-Meyer Institute, University of Nebraska Medical Center,

444 South 44th Street, Omaha, NE 68105, USA 